\title{
ISOLASI DAN IDENTIFIKASI MIKROORGANISME DALAM LUMPUR AKTIF PENGOLAHAN LIMBAH INDUSTRI KULIT
}

\author{
Prayitno, Titik P. Widowati, Puji Ediari S., dan R. Jaka Susila
}

\begin{abstract}
INTISARI
Penelitian ini bertujuan untuk mengisolasi dan mengidentifikasi mikro organisme yang tumbuh sebagai lumpur aktif yang digunakan dalam pengolahan limbah cair industri penyamakan kulit. Hasil penelitian menunjukkan protozoa yang tumbuh dalam lumpur aktif yaitu protozoa kelompok $\beta$ mesosaprobik. Selain itu juga terdapat bakteri gram negatif berbentuk bulat (Zoogloea) dan bakteri gram positif berbentuk batang (Sphaerotillus). Dari isolasi dan identikasi jenis mikroorganisme yang ada pada lumpur aktif dapat disimpulkan limbah cair yang diolah pada kondisi pencemaran tingkat sedang.
\end{abstract}

ABSTRACT

The aim of this research is to isolate and to identify the microorganisms that grow as activated sludge used in the tannery wastewater treatment plant. The result shows that the protozoa in the activated sludge were $\beta$ mesosaprobik protozoa. Other microorganisms in the sludge were spherical - gram negative bacteria (Zoogloea) and cylindrical - gram positive bacteria (Sphaerotillus). It is therefore can be concluded that the wastewater which treated with the activated sludge was medium polluted condition.

\section{PENDAHULUAN}

Industri penyamakan kulit merupakan industri yang mengolah kulit mentah menjadi kulit tersamak, pengertian ini meluas mencakup teknologi penyempurnaan (finishing) sehingga produk akhirnya adalah kulit jadi (leather).

Proses konversi kulit mentah menjadi kulit tersamak melalui teknologi proses baik kimiawi maupun mekanis atau keduanya dilakukan bersama atau silih berganti. Karakteristik proses penyamakan kulit menggunakan banyak air, banyak bahan kimia, serta banyak menghasilkan limbah baik cair, padat maupun gas.

Untuk mewujudkan industri kulit yang berwawasan lingkungan, maka dalam kegiatan produksinya industri perkulitan harus melaksanakan pengendalian pencemaran limbahnya terhadap lingkungan. Sejalan dengan telah diberlakukannya baku mutu untuk limbah industri kulit, mau tidak mau industri pengolahan kulit baik skala besar, menengah maupun kecil dalam operasinya harus juga dilengkapi dengan suatu unit pengolah limbah cair agar limbah yang dihasilkannya dapat memenuhi baku mutu limbah yang telah ditetapkan.

Pengolahan limbah cair industri kulit dapat dilakukan dengan melalui tahapan yang berupa pengolahan primer dan pengolahan sekunder. Activated sludge (lumpur aktif) banyak digunakan dalam pengolahan sekunder limbah industri penyamakan kulit. Proses tersebut terutama dimaksudkan untuk menurunkan Biological Oxygen Demand (BOD) dan padatan 
terlarut dalam limbah cair melalui degradasi komponen limbah oleh mikroorganisme tertentu sesuai dengan tingkat cemarannya. Jenis-jenis mikroorganisme dalam lumpur aktif memprediksikan tingkat cemaran limbah yang diolahnya (Bosnic dkk., 1997). Lumpur aktif merupakan massa mikroorganisme yang terdiri dari bakteri, protozoa, ganggang dan metazoa bercampur dengan lumpur yang terdiri dari bahan-bahan organik. Mikroorganisme yang ada dalam lumpur aktif akan melakukan perombakan senyawa limbah yang terserap dalam lumpur maupun yang ada dalam limbah cair.

Dalam lumpur aktif akan terjadi mekanisme perombakan unsur secara berantai. Bakteri yang merupakan kelompok terkecil dari mikroorganisme pertama kali mengurai zat-zat organik dalam limbah. Selanjutnya bakteri ini akan dimakan oleh protozoa yang juga akan mencerna zat-zat organik lainnya. Ganggang berperan dalam proses pengolahan limbah cair melalui pelepasan oksigen dalam jumlah yang cukup besar selama proses photosintesis seperti yang dilakukan oleh algae atau phytoplankton yang berkhloroplast. Metazoa merupakan organisme multi seluler, metazoa yang digunakan untuk mengolah limbah cair mempunyai banyak variasi mulai dari rotaria yang mempunyai tubuh-tubuh kecil sampai organisme yang relatif besar seperti moluska, larva dan insekta yang hidup dalam kolam oksidasi biologi atau danau dipinggir laut (Murtinah, 1994).

Persoone dan Pauw (1986) menyatakan bakteri yang merupakan perombak biologi utama tentu ada dalam limbah cair kecuali pada limbah cair yang sangat beracun dan atau limbah radioaktif. Lebih lanjut dikatakan bahwa jenis mikroorganisme yang tumbuh dalam lumpur aktif dapat dijadikan indikator biologis terjadinya pencemaran limbah cair yang diolahnya yang dikenal dengan istilah sistem saprobik. Berdasarkan pengamatan mikroskopis terhadap limbah secara langsung dikenal tiga kategori organisme saprobik yaitu 1). Organisme polisaprobik yang mempunyai 34 jenis protozoa spesifik yang mungkin hidup didalam lumpur aktifnya sebagai indikator biologis bahwa limbah cair tersebut sangat tercemar, 2). Organisme mesosaprobik yang dibagi menjadi dua kelompok organisme yaitu a mesosaprobik sebagai indikator air yang tingkat cemarannya tinggi dengan 17 jenis protozoa yang tumbuh didalamnya dan kelompok organisme $\beta$ mesosaprobik dengan 22 jenis protozoa sebagai indikator pada air yang tingkat cemaran sedang serta 3 ). Organisme oligosaprobik dengan 22 jenis protozoa sebagai indikator pada limbah cair yang tingkat cemarannya rendah. Keberadaan protozoa dan bakteri dapat digunakan sebagai indikator tingkat pencemaran limbah cair yang harus diolah suatu perusahaan.

Tujuan penelitian ini adalah untuk isolasi dan identifikasi mikroorganisme khususnya protozoa dan bakteri untuk mengetahui tingkat pencemaran limbah cair yang dihasilkan industri penyamakan kulit. Terdapatnya berbagai jenis protozoa dan koloni bakteri mempunyai kaitan yang erat dengan tingkat cemaran limbah cair. Pada tingkat cemaran tinggi akan dijumpai protozoa tipe polisabrobik, pada tingkat cemaran sedang akan dijumpai protozoa tipe mesosaprobik sedang pada tingkat cemaran limbah yang ringan hanya akan dijumpai protozoa tipe oligosaprobik. Dengan mengetahui jenis mikroorganisme yang tumbuh dalam lumpur aktif maka akan dapat diketahui kategori pencemaran limbah yang ada sehingga nantinya dapat diprediksi cara-cara penanganan limbah yang harus dilakukan perusahaan. 


\title{
BAHAN DAN METODA PENELITIAN
}

\section{Bahan}

- Lumpur aktif dari instalasi pengolahan limbah cair industri penyamakan kulit PT Budi Makmur Jayamurni.

- Media tumbuh mikroorganisme, antara lain : bacto agar (Oxoid), pepton (Oxoid), beefextract (Oxoid).

- Bahan untuk pengecatan antara lain : crystal violet (Merck), Lugol Jod (Merck) safronin (Merck), karbol fuchsin, alkohol 95\%, aceton.

\begin{abstract}
Alat
Alat yang digunakan dalam penelitian ini antara lain : autoclave, mikroskop dan alatalat gelas untuk pembuatan kultur dan pembiakan.
\end{abstract}

\section{Metoda Penelitian}

Penelitian dilakukan dalam dua tahapan. Tahap pertama adalah isolasi dan identifikasi jenis protozoa dan tahap kedua adalah isolasi dan identifikasi genus bakteri yang tumbuh pada lumpur aktif.

Tahap pertama dilakukan sesegera mungkin setelah contoh lumpur aktif diambil. Pada tahap ini dilakukan pengamatan jenis protozoa secara mikroskopis langsung menggunakan mikroskop biasa dengan perbesaran sedang ( $45 \mathrm{kali}$ ). Hasil pungamatan kemudian digambar dan dicocokkan dengan gambar organisme dalam sistem saprobik Persoone dan Pauw (1986) serta dilihat motilitasnya. Tahap kedua meliputi isolasi bakteri yang tumbuh dalam lumpur aktif tersebut dan mengidentifikasi sifat morfologisnya. Isolasi bakteri dilakukan sesuai cara Atlas dkk. (1984). Identifikasi morfologis dilakukan terhadap warna koloni, bentuk koloni pada media agar tegak dan petridish, bentuk sel bakteri, pengecatan gram, pengecatan flagella dan sifat proteolitik bakteri. Identifikasi morfologi sel dan koloni serta pengujian sifat proteolitik bakteri sesuai cara Atlas dkk. (1984).

Dari hasil isolasi dan identifikasi jenis protozoa dalam lumpur aktif ini dibandingkan dengan jenis protozoa dalam sistem saprobik Persoone dan Pauw (1986) akan dapat diketahui sistem saprobik contoh. Isolasi dan identifikasi bakteri dilakukan sampai tingkat genus dengan melihat morfologi dan sifat biokimiawi bakteri yang dicocokkan dengan Bergey's Manual (Sneath dkk., 1989).

\section{HASIL PENELITIAN DAN PEMBAHASAN}

\section{Pengamatan protozoa}

Pengamatan jenis protozoa dilakukan secara mikroskopis langsung terhadap lumpur aktif. Penentuan jenis protozoa dilakukan dengan jalan membandingkan antara hasil pengamatan mikroskopis dengan gambar sistem saprobik menurut Persoone dan Pauw (1986).

Dari pengamatan langsung ini dapat diketahui jenis protozoa yang ada dalam lumpur aktif yang digunakan dalam pengolahan limbah cair industri kulit adalah sebagai berikut 
1. Astervonella formosa

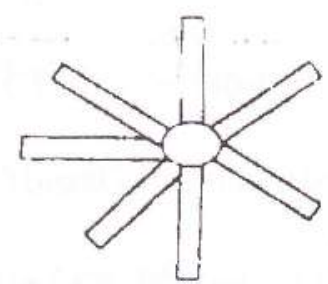

3. Melosira varians

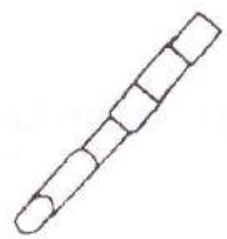

5. Euploten charon

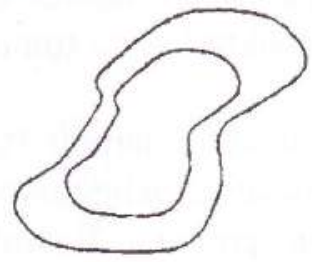

2. Oscillabarik rubescens

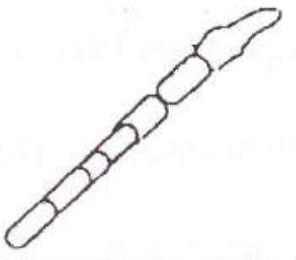

4. Scendesmus quadicanda

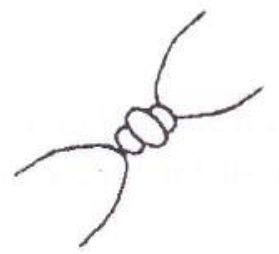

6. Vorticella campanula

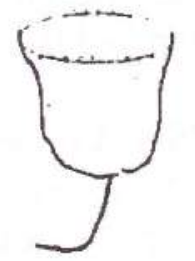

Berdasarkan sistem saprobik Persoone dan Pauw (1986), ke-enam jenis mikrobia tersebut termasuk dalam kelompok organisme $\beta$ mesosaprobik. Selanjutnya Persoone dan Pauw (1986) juga menyatakan bahwa apabila sebagian besar jenis mikroorganisme yang ada pada limbah cair termasuk dalam salah satu kelompok organisme dalam sistem saprobik dimaksud maka dapat dipastikan tingkat cemaran limbah cairnya sesuai dengan yang ditunjukkan dalam sistem tersebut. Hal ini dimaksudkan bahwa dengan dijumpainya kelompok organisme $\beta$ mesosaprobik, maka berarti sampel limbah cair tersebut dalam tingkat cemaran sedang.

Dilihat dari motilitas protozoa dalam lumpur, ada mikroorganisme yang bersifat motil (bergerak) sangat cepat, bergerak lamban dan ada yang statis (diam). Hasil pengamatan menunjukkan Vorticella campanula merupakan protozoa dalam limbah yang paling aktif pergerakkannya, sedang lainnya kurang aktif. Vorticella campanula memang merupakan jenis protozoa yang keberadaannya dengan motilitas yang tinggi merupakan ciri utama kondisi limbah cair dengan tingkat cemaran sedang (Metcalf dan Eddy, 1983).

\section{Isolasi dan identifikasi bakteri}

Dari hasil isolasi bakteri lumpur aktif pada agar miring dan cawan petridish diperoleh tiga isolat bakteri yang dominan, yaitu :

1. Isolat berwarna putih keruh, bentuk koloni irregular.

2. Isolat berwarna putih kekuningan, bentuk koloni irregular.

3. Isolat berwarna putih keruh, bentuk koloni circulair. 

kut :

Identifikasi sel bakteri terhadap masing-masing isolat menunjukkan hasil sebagai beri-

1. Isolat berwarna putih keruh bentuk irregular dan isolat berwarna putih kekuningan bentuk irregular merupakan bakteri berbentuk batang dengan sifat pengecatan gram positif.

2. Isolat berwarna putih keruh bentuk circulair merupakan bakteri berbentuk bulat dengan sifat pengecatan gram negatif.

Hasil pengecatan flagela menggunakan karbol fuchsin menunjukkan bahwa tidak tampak flagela yang tercat, hal mana dapat diartikan bahwa bakteri tersebut tidak berflagella atau mempunyai flagella namun tidak dapat terwarnai oleh karbol fuchsin (colourless flagella).

Berdasarkan hasil pengamatan besarnya zona terdegradasi pada media skim-agar yang digunakan untuk menumbuhkan ketiga isolat bakteri dapat dikatakan bakteri-bakteri mempunyai sifat proteolitik yang cukup baik. Hal mana menunjukkan bahwa lumpur aktif yang dipakai untuk mengolah limbah organik lazim mengandung banyak bakteri yang sifatnya proteolitik yang berperanan dalam mendegradasi bahan organik terutama protein dalam limbah cair yang diolahnya.

Pengolahan limbah cair industri secara biologis dipengaruhi oleh banyak faktor, salah satu faktor yang mempengaruhi keberhasilan adalah jenis dan jumlah mikrobia yang terdapat didalam reaktor biologis. Metcalf dan Eddy (1983) juga menyatakan protozoa dan bakteri mempunyai peran sangat besar pada pendegradasian zat-zat organik limbah cair secara biologis. Selanjutnya Persoone dan Pauw (1986) menyatakan bakteri adalah merupakan kelompok terkecil dari mikroorganisme yang mengurai pertama kali zat organik dalam air limbah guna pertumbuhan dan perbanyakan selnya.

Hasil identifikasi bakteri menunjukkan diperolehnva isolat bentuk circulair dengan warna putih keruh yang setelah dilakukan pengecatan gram, ternyata merupakan bakteri gram negatif dengan bentuk sel bulat, flagella tidak tampak jelas serta mempunyai daya proteolotik bakteri ini termasuk genus Zoogloea (Sneath, 1986). Lebih lanjut Sneath (1986) menyatakan bakteri genus Zoogloea banyak tersebar di alam, air dengan tingkat pencemaran sedang dan unit-unit pengolahan air limbah secara aerobik. Hal tersebut juga sesuai dengan pendapat Persoone dan Pauw (1986) yang menyatakan pada pengolahan limbah cair kondisi dengan oksigen yang terbatas ada dua jenis mikroorganisme yang dominan yang termasuk genus bakteri yaitu Zoogloea dan Sphaerotillus. Zoogloea merupakan bakteri yang mempunyai peranan sangat besar dalam membentuk koloni biologis atau membran biologis. Bentuk koloni bakteri ini tidak beraturan dan circulair. Genus bakteri lain adalah sphaerotillus, tubuh individu ini disusun dalam garis membentuk filamen yang kebanyakan berwarna abu-abu dan keputihputihan.

Hasil identifikasi juga menunjukkan terdapatnya isolat warna keruh dan warna putih kekuningan bentuk irregular, ternyata bakteri ini termasuk jenis gram positif dengan bentuk batang serta mempunyai sifat proteolitik. Bakteri tersebut besar kemungkinan adalah genus Sphaerotillus. Hal ini didukung oleh pendapat Persoone dan Pauw (1986) yang menyatakan Sphaerotillus secara luas memang terdapat pada bangunan-bangunan pengolahan limbah cair dengan tingkat cemaran sedang. 


\section{KESIMPULAN}

Dari hasil penelitian ini dapat disimpulkan :

1. Pengamatan langsung secara mikroskopis menunjukkan bahwa jenis protozoa yang hidup adalah dari jenis protozoa $\beta$ mesosaprobik.

2. Bakteri yang mengambil bagian dalam proses degradasi biologis zat-zat organik pada limbah cair industri penyamakan kulit termasuk genus Zoogloea dan Sphaerotillus.

3. Limbah cair industri penyamakan kulit termasuk dalam kategori tingkat pencemaran sedang.

\section{DAFTAR PUSTAKA}

Atlas, R. M.; Brown, A.E.; Dobra, K.W dan Miller, L. 1984. Experimental Microbiology. Macmillan Publishing Company, New York.

Bosnic, M.; Buljan, J. dan Daniels, R.P. 1997. Pollutant in Tannery Effuents. Definitions and Environmental Impact in Limit for Discharge into Water Bodies and Sewers Regional Workshop on Design, Spesification and maintenance of Effluent Treatment Plants. UNIDO, Madras.

Metcalf dan Eddy, I. 1983. Waste Water Engineering Disposal Reuse, 2 nd. Tata Mc. Graw Hill Publishing Company Ltd, New Delhi.

Murtinah S. 1994. Dasar-dasar Teknologi Pengendalian Pencemaran Oleh Air Limbah Industri. Makalah pada Pendidikan dan Latihan Teknologi Pengendalian Limbah Industri Tingkat Supervisor Subsektor ILME tanggal 10-16 Oktober 1997, Semarang.

Persoone, G. dan Pauw, N.D. 1986. Systems of Biological Indicators for Water Quality Assesment. J. WPCF 48 (9) : 39-73.

Sneath, P.H.A.; Nicholas, S.M.; Sharpe, M.E. dan Halt, J.G. 1986. Bergey's Manual of Systematic Bacteriology Vol.2. William \& Walkin, New York. 